\title{
Permeation Properties of Bacterial Concrete
}

\author{
Srinivasa Reddy V ${ }^{1}$, Sreenivasa Rao D ${ }^{1}$, Seshagiri Rao M V ${ }^{1}$, Sasikala Ch $^{2}$ \\ ${ }^{I}$ Dept. of Civil Engg. JNTUH College of Engineering, Hyderabad, India. \\ ${ }^{2}$ Centre for environment, JNTU, Hyderabad, India.
}

\begin{abstract}
An experimental study on effect of calcifying bacteria on permeation properties (such as absorptivity and sorptivity) of bacterial concrete is outlined in this paper. The rate of water absorption, water absorption capacity, sorptivity and porosity tests were then performed on the samples of concrete treated with bacteria of ordinary (M20), standard (M40) and high strength (M60 and M80) grades, to assess the enhancement of permeation properties due to biomineralization in bacterial concrete. The results show that, absorptivity, sorptivity and porosity of bacterial concrete are much lower than the corresponding characteristics of controlled concrete. These characteristics are noticeably enhanced by the addition of bacillus subtilis JC3 to the concrete. It also indicated from the chemical analysis that the cement-phase composition of bacterial concrete has significant amount of calcium precipitate compound. The study of porosity is fundamental for understanding phenomena of water transport within pore structure and interactions between concrete and water. Water can penetrate a solid because there are interconnected channels (pores) inside the solid that facilitate its transportation.The long-term durability of concrete is affected to a large extent by its permeability. Therefore, the permeation properties, rather than mechanical properties, are the important factors to study in relation to concrete durability. As a consequence, a considerable effort has to be directed toward investigation of such properties in the present study.
\end{abstract}

Keywords - bacterial concrete, bacillus subtilis JC3, Permeation, Porosity, Sorptivity, Water Absorption Capacity.

\section{Introduction}

Reinforced concrete structures are exposed to harsh environments, yet often expected to last with little or no repair or maintenance for long periods of time. To do this, a durable structure needs to be produced. One of the major forms of environmental attack is chloride ingress, which leads to corrosion of the reinforcing steel and a subsequent reduction in the strength, serviceability, and aesthetics of the structure. This may lead to early repair or premature replacement of the structure. A common method of preventing such deterioration is to prevent chlorides from penetrating the structure to the level of the reinforcing steel bar by using relatively impenetrable concrete. Capillary absorption, hydrostatic pressure, and diffusion are the means by which chloride ions can penetrate concrete.

One of the potential applications of microbiologically induced calcite precipitation (MICP) is conservation of architectural heritage, historic structures and materials and their restoration treatments [1]. Most building materials, both natural (stones) and artificial (bricks, cement mortar and concrete), contain a certain volume of empty space which is distributed within the solid mass in the form of pores, cavities, and cracks of various shapes and sizes. The total sum of these empty spaces is called porosity, a fundamental characteristic of building construction material that affects its physical properties (mechanical strength, durability, etc.).The knowledge of their pore structure is an important parameter for characterizing building materials in predicting their behavior under weathering conditions and for evaluating the degree of deterioration and establishing the effectiveness of conservation treatments of their surfaces. The percentage distribution of pores of differing radius within the material is an extremely important parameter for the evaluation of its behaviour when in contact with water. The size of the pores, their distribution and geometry are fundamental factors in determining the properties of materials and their suitability for building applications. One of the main causes of deterioration is the interaction between water and the porous structure [2]. Concrete can be viewed as a porous composite material due to the presence of pores and unfilled voids caused by improper grading of aggregates, lack of enough cement paste, incomplete compaction, bleeding, by air entraining, if used, and inadequate degree of hydration of cement. Perviousness of concrete, like other porous materials, is expressed in terms of permeability, which is defined as the rate at which water or other fluids can penetrate through concrete under a pressure head [3]. Permeability is regarded as an important material property for concrete construction, as its affects the durability of concrete exposed to aggressive environments. Permeability of concrete is not a function of porosity alone, it depends on the porosity, pore size and distribution, and tortuosity of pore channels in concrete [4]. 


\subsection{Water Absorption Capacity Test}

\section{Experimental Programme}

As per ASTM C642 (13) "Standard Test Method for Density, Absorption, and Voids in Hardened Concrete" [5], this test measures the water absorption rate and the maximum water absorption capacity. The total quantity of water absorbed is related to the total open porosity, while the kinetics of the process depends principally on the distribution of the pore sizes. The maximum quantity of water absorbed by a material at room temperature and pressure under conditions of saturation is expressed as a percentage of the dry mass of the sample. This test also measures the capillary rise of water, the most common form of liquid water migration in concrete. It is inversely proportional to the diameter of the pores; the smaller the diameter the greater the capillary absorption. Absorption is the capacity of a sample to hold water while sorptivity is the rate at which the sample fills the sample.

\subsubsection{Procedure}

1. Concrete cube samples of size $100 \times 100 \times 100 \mathrm{~mm}$ are casted and cured for 28 days for testing.

2. Wash the samples in the deionized water before beginning this test in order to eliminate powdered material from the surface. Dry the samples in the oven for 24 hours at $60^{\circ} \mathrm{C}$ (this relatively low drying temperature will prevent the deterioration of organic substances in the case of treated samples).

3. Weigh the samples. Repeat the drying process until the mass of the each sample is constant, that is, until the difference between 2 successive measurements, at an interval of 24 hours, is no more than $0.1 \%$ of the mass of the sample.

4. Once the samples have been completely dried and the constant mass recorded $\left(\mathrm{m}_{\mathrm{o}}\right)$, place them in a container or beaker, on a base of glass rods and slowly cover with deionized water until they are totally immersed with about $2 \mathrm{~cm}$ of water above them.

5. At programmed intervals of time, take each sample out of the container, blot it quickly with a damp cloth to remove surface water, and then record the mass of the wet samples $\left(\mathrm{m}_{\mathrm{i}}\right)$ and the time of measurement on the data sheet.

6. Re-immerse the samples in water and continue measuring until the difference in weight between 2 successive measurements at 24-hour intervals is less than $1 \%$ of the amount of water absorbed

7. At this point, take the samples out of the water and dry them again in an oven at $60^{\circ} \mathrm{C}$ until they have reached constant mass (as above). Record this value $\left(\mathrm{m}_{\mathrm{d}}\right)$ on the data sheet. Proceed with the calculations.

a) At each interval, the quantity of water absorbed with respect to the mass of the dry sample is expressed as:

$$
\mathrm{M}_{\mathrm{i}} \%=100 \times\left(\mathrm{m}_{\mathrm{i}}-\mathrm{m}_{\mathrm{o}}\right) / \mathrm{m}_{\mathrm{o}}
$$

Where $\mathrm{m}_{\mathrm{i}}=$ weight $(\mathrm{kg})$ of the wet sample at time $\mathrm{t}_{\mathrm{i}} ; \mathrm{m}_{\mathrm{o}}=$ weight $(\mathrm{kg})$ of the dry sample

b) Record these values on a data sheet and on a graph as a function of time.

c) From the recorded data sheet, calculate the water absorption capacity (WAC) as shown below:

$$
\mathrm{WAC}=100 \times\left(\mathrm{m}_{\max }-\mathrm{m}_{\mathrm{d}}\right) / \mathrm{m}_{\mathrm{d}}
$$

Where $\mathrm{m}_{\max }=$ the mass $(\mathrm{kg})$ of the sample at maximum water absorption $\mathrm{m}_{\mathrm{d}}=$ the mass $(\mathrm{kg})$ of the sample after re-drying at the end of the test

The length of the intervals during the first 24 hours depends on the absorption characteristics of the materials. concrete samples should be weighed a few minutes after immersion, and then at increasing intervals (15 min, 30 min, 1 hour, etc.) for the first 3 hours. All samples should then be weighed 8 hours after the beginning of the test and then at 24- hour intervals until the quantity of water absorbed in two successive measurements is not more than $1 \%$ of the total mass.

\subsection{Porosity Test}

This test was conducted to estimate the percentage of voids present in the bacterial specimens. First of all saturated weights $\mathrm{W}_{\text {sat }}$ of the specimens were taken. Then bacterial specimens were dried in oven at about $105^{\circ} \mathrm{C}$ until constant mass $\mathrm{W}_{\mathrm{dry}}$ was obtained. Then weight of water absorbed $\mathrm{W}_{\mathrm{w}}$ was calculated in grams, which was converted to cc, which signifies the volume of voids present within the specimen. The test was conducted on $100 \mathrm{~mm} \times 200 \mathrm{~mm}$ size cylinders of controlled and bacterial specimen mixes of ordinary (M20), Standard (M40) and High strength (M60) grades of concrete at 28, 60 and 90 days age. Porosity of concrete is usually determined by dividing the volume of voids of the sample by its bulk volume. Bulk volume of each sample is determined using the measured lengths and diameters of the samples. Volume of voids for each sample is determined by subtracting its grain volume (the volume of the solid portion of concrete excluding the volume of pores) from its bulk volume.

Finally porosity ' $\eta$ ' or percentage of interconnected pore space was calculated using the formula given below

$$
\eta=\left(\mathrm{V}_{\mathrm{v}} / \mathrm{V}\right) \times 100=\left(\mathrm{W}_{\text {sat }}-\mathrm{W}_{\mathrm{dry}}\right) \times 100 / \mathrm{V}=\mathrm{W}_{\mathrm{w}} \mathrm{X} 100 / \mathrm{V}
$$


Where, $\mathrm{V}_{\mathrm{v}}=$ volume of voids in $\mathrm{cc}=\mathrm{W}_{\mathrm{sat}}-\mathrm{W}_{\mathrm{dry}}$ in grams ;

$\mathrm{V}=$ total volume of specimen in $\mathrm{cc}=\pi \mathrm{r}^{2} \mathrm{~h}=3.14 \times 50 \times 50 \times 200=1.57 \times 10^{6} \mathrm{~mm}^{3}$

The following equation was used to find the apparent porosity [6].

$$
\text { Apparent porosity }=\left[\left(\mathrm{M}_{\mathrm{w}}-\mathrm{M}_{\mathrm{d}}\right) /\left(\mathrm{M}_{\mathrm{w}}-\mathrm{M}_{\mathrm{s}}\right)\right] \times 100 \%
$$

Where $\mathrm{M}_{\mathrm{w}}$ = weight of saturated specimen (after immersion in water for 48 hours, it is removed and surface dried),

$$
M_{d}=\text { Weight of specimen after oven drying and } M_{s}=\text { weight of specimen while suspended in water }
$$

As per ASTM C642, the Volume of permeable voids (VPV) was evaluated using the formula:

Volume of permeable pore space in concrete $(\%)=\left(1-\mathrm{SG}_{\mathrm{b}} / \mathrm{SG}_{\mathrm{a}}\right) \times 100$

Where

$$
\begin{aligned}
& \text { Concrete bulk dry specific gravity }\left(\mathrm{SG}_{\mathrm{b}}\right)=\mathrm{M}_{\mathrm{d}} /\left(\mathrm{M}_{\mathrm{w}}-\mathrm{M}_{\mathrm{s}}\right) \\
& \text { Concrete apparent specific gravity }\left(\mathrm{SG}_{\mathrm{a}}\right)=\mathrm{M}_{\mathrm{d}} /\left(\mathrm{M}_{\mathrm{d}}-\mathrm{M}_{\mathrm{s}}\right)
\end{aligned}
$$

Concrete bulk dry specific gravity considers both permeable and impermeable voids where as apparent specific gravity considers only impermeable voids [7].

\subsection{ASTM C1585 Sorptivity Test}

Sorptivity is a measure of the capillary forces exerted by the pore structure causing fluids to be drawn in to the body of the material. It provides a relative measure that combines pore size diameter and number of pores. While theoretically possible to consider the flow in any geometry, it is too mathematically complex to be of any practical use except where there are one dimensional flow conditions [8]. Determining the sorptivity of a sample in the lab is a simple, low technology technique, all that is required, is a scale, a stopwatch and a shallow tub of water. The samples (100 x $50 \mathrm{~mm}$ size cylindrical specimens) are preconditioned to a certain moisture condition, either by drying the sample for 7 days in a $50^{\circ} \mathrm{C}$ oven. The sides of the concrete sample are sealed, typically with electrician's tape or by sealant while the suction face and the face opposite it were left unsealed. The initial mass of the sample is taken and at time 0 , is immersed to a depth of 5-10 $\mathrm{mm}$ in the water. The procedure was repeated, consecutively, at various times such as $15 \mathrm{~min}, 30 \mathrm{~min}, 1 \mathrm{hr}, 2 \mathrm{hr}, 4 \mathrm{hr}, 6 \mathrm{hr}, 24 \mathrm{hr}, 48$ $\mathrm{hr}$ and $72 \mathrm{hr}$ until the last reading. The gain in mass per unit area over the density of water (I) is plotted versus the square root of the elapsed time $(\sqrt{ } \mathrm{t})$. The slope of the line of best fit of these points (ignoring the origin) is reported as the sorptivity (k). Cylindrical concrete specimens were placed on a filtered support (sponge) so that the water level was $10 \pm 1 \mathrm{~mm}$ above the inflow face as shown in Fig. 1. For one dimensional flow, it can be stated that [Hall, 1989]:

$$
\mathrm{I}=\mathrm{k} \times \sqrt{ } \mathbf{t}
$$

Where $\mathrm{k}$ is sorptivity coefficient and $\mathrm{I}=\mathrm{W} /(\mathrm{A} \mathrm{x} \mathrm{d})$

$\mathrm{W}=$ the amount of water absorbed in $\mathrm{kg}$

$\mathrm{A}=$ the cross-section of the specimen that was in contact with water $\left(\mathrm{m}^{2}\right)$

$\mathrm{d}=$ density of the medium in which the specimen was dipped $\left(1000 \mathrm{~kg} / \mathrm{m}^{3}\right.$ in case medium is water $)$

The rate of water absorption, sorptivity (k), is the slope of $\mathrm{I}-\sqrt{t} \operatorname{graph}\left(\mathrm{m} / \mathrm{min}^{1 / 2} \mathrm{or} \mathrm{kg} / \mathrm{m}^{2} / \sqrt{\mathrm{min}}\right)$.

Because of small initial surface tension and buoyancy effects, the relationship between cumulative water absorption $\left(\mathrm{kg} / \mathrm{m}^{2}\right)$ and square root of exposure time $\left(\mathrm{t}^{0.5}\right)$ shows deviation from linearity during first few minutes. Thus, for the calculation of sorptivity coefficient, only the section of the curves for exposure period from $15 \mathrm{~min}$ to $72 \mathrm{hrs}$, where the curves were consistently linear, was used for the calculation of Sorptivity [9]. While volume of permeable voids (VPV) is a measure of voids, Sorptivity gives a measure of nominal pore radius and number of pores [10]. 

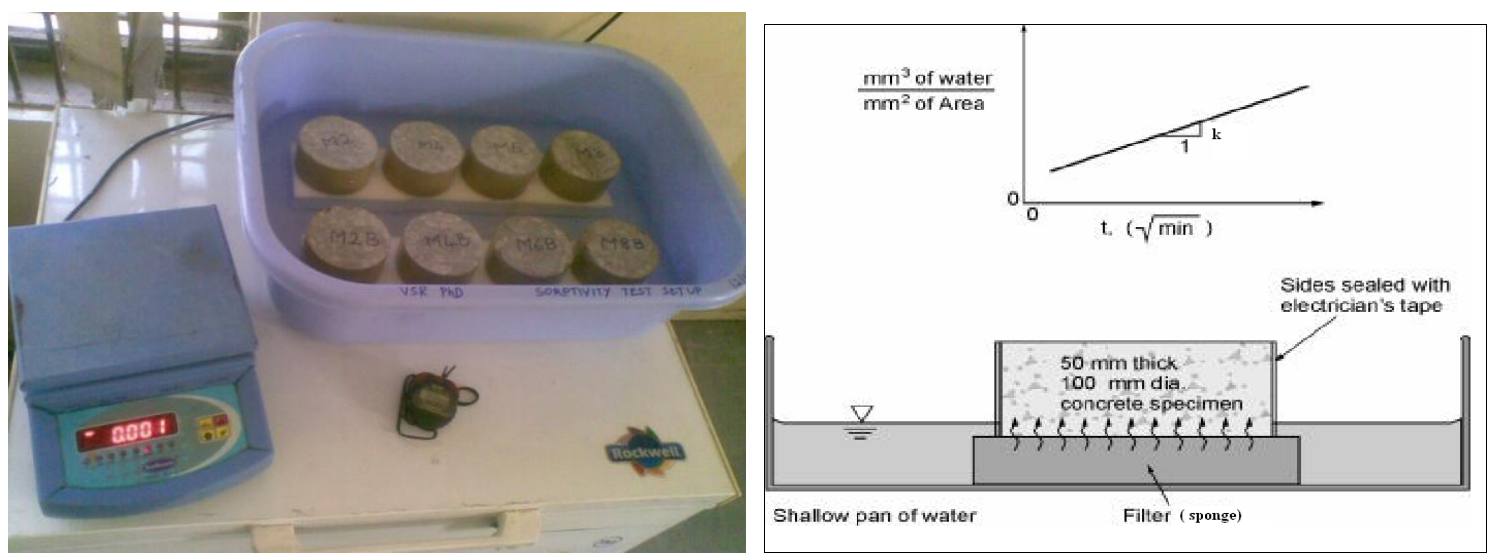

Fig 1: Experimental Setup for Sorptivity Test

III. Test Results

Table 1: Elemental Composition of Controlled Concrete and Bacterial Concrete samples

\begin{tabular}{|c|c|c|c|c|c|c|c|}
\hline \multicolumn{9}{|c|}{ Controlled Specimen } & \multicolumn{5}{c|}{ Bacterial Specimen } \\
\hline Element & $\begin{array}{c}\text { Element } \\
\text { Percentage }\end{array}$ & Compound & $\begin{array}{c}\text { Compound } \\
\text { Percentage }\end{array}$ & Element & $\begin{array}{c}\text { Element } \\
\text { Percentage }\end{array}$ & Compound & $\begin{array}{c}\text { Compound } \\
\text { Percentage }\end{array}$ \\
\hline $\mathrm{Na}$ & 0.3 & $\mathrm{Na}_{2} \mathrm{O}$ & 0.4 & $\mathrm{Na}$ & 0.5 & $\mathrm{Na}_{2} \mathrm{O}$ & 0.7 \\
\hline $\mathrm{Mg}$ & 0.05 & $\mathrm{MgO}$ & 0 & $\mathrm{Mg}$ & 0.6 & $\mathrm{MgO}$ & 1.0 \\
\hline $\mathrm{Al}$ & 7.1 & $\mathrm{Al}_{2} \mathrm{O}_{3}$ & 13.5 & $\mathrm{Al}$ & 0.2 & $\mathrm{Al}_{2} \mathrm{O}_{3}$ & 0.4 \\
\hline $\mathrm{Si}$ & 25.9 & $\mathrm{SiO}_{2}$ & 59.6 & $\mathrm{Si}$ & 1.0 & $\mathrm{SiO}_{2}$ & 2.2 \\
\hline $\mathrm{S}$ & 0 & $\mathrm{SO}_{3}$ & 0 & $\mathrm{~S}$ & 0 & $\mathrm{SO}_{3}$ & 0 \\
\hline $\mathrm{Cl}$ & 0.2 & & & $\mathrm{Cl}$ & 0 & & 0 \\
\hline $\mathrm{K}$ & 15.2 & $\mathrm{~K}_{2} \mathrm{O}$ & 18.4 & $\mathrm{~K}$ & 0 & $\mathrm{~K}_{2} \mathrm{O}$ & 0 \\
\hline $\mathrm{Ca}$ & 8.4 & $\mathrm{CaO}$ & 10.7 & $\mathrm{Ca}$ & 69.3 & $\mathrm{CaO}$ & 92.7 \\
\hline $\mathrm{Fe}$ & 0.3 & $\mathrm{Fe}_{2} \mathrm{O}_{3}$ & 0.4 & $\mathrm{Fe}$ & 0 & $\mathrm{Fe}_{2} \mathrm{O}_{3}$ & 0 \\
\hline $\mathrm{O}$ & 42.5 & & & $\mathrm{O}$ & 29.2 & & \\
\hline
\end{tabular}

Table 2: Water Absorption at different time intervals of controlled and bacterial concrete for different grades

\begin{tabular}{|c|c|c|c|c|c|c|c|c|}
\hline \multirow{2}{*}{$\begin{array}{c}\text { Measurement } \\
\text { Intervals } \\
\mathrm{t}_{\mathrm{i}}(\mathrm{min})\end{array}$} & \multicolumn{7}{|c|}{$\mathrm{M} 20$} & \multicolumn{2}{c|}{ M 40} & \multicolumn{2}{c|}{$\mathrm{M} 60$} & \multicolumn{2}{c|}{$\mathrm{M} 80$} \\
\cline { 2 - 9 } & $\mathrm{m}_{\mathrm{o}}=2.49 \mathrm{~kg}$ & $\mathrm{~m}_{\mathrm{o}}=2.51 \mathrm{~kg}$ & $\mathrm{~m}_{\mathrm{o}}=2.59 \mathrm{~kg}$ & \multicolumn{2}{c|}{$\mathrm{m}_{\mathrm{o}}=2.63 \mathrm{~kg}$} \\
\cline { 2 - 9 } & $\mathrm{m}_{\mathrm{i}}(\mathrm{kg})$ & $\mathrm{M}_{\mathrm{i}}(\%)$ & $\mathrm{m}_{\mathrm{i}}(\mathrm{kg})$ & $\mathrm{M}_{\mathrm{i}}(\%)$ & $\mathrm{m}_{\mathrm{i}}(\mathrm{kg})$ & $\mathrm{M}_{\mathrm{i}}(\%)$ & $\mathrm{m}_{\mathrm{i}}(\mathrm{kg})$ & $\mathrm{M}_{\mathrm{i}}(\%)$ \\
\hline 0 & 2.49 & 0.00 & 2.51 & 0.00 & 2.59 & 0.00 & 2.65 & 0.00 \\
\hline 15 & 2.51 & 0.80 & 2.55 & 1.59 & 2.61 & 0.77 & 2.66 & 0.38 \\
\hline 30 & 2.59 & 4.02 & 2.56 & 1.99 & 2.62 & 1.16 & 2.67 & 0.75 \\
\hline 60 & 2.60 & 4.42 & 2.58 & 2.79 & 2.63 & 1.54 & 2.67 & 0.75 \\
\hline 90 & 2.61 & 4.82 & 2.58 & 2.79 & 2.64 & 1.93 & 2.67 & 0.75 \\
\hline 180 & 2.62 & 5.22 & 2.58 & 2.79 & 2.64 & 1.93 & 2.67 & 0.75 \\
\hline 480 & 2.62 & 5.22 & 2.58 & 2.79 & 2.64 & 1.93 & 2.67 & 0.75 \\
\hline 1440 & 2.63 & 5.62 & 2.58 & 2.79 & 2.64 & 1.93 & 2.67 & 0.75 \\
\hline 2880 & 2.63 & 5.62 & 2.58 & 2.79 & 2.64 & 1.93 & 2.67 & 0.75 \\
\hline
\end{tabular}

\begin{tabular}{|c|c|c|c|c|c|c|c|c|}
\hline \multirow{3}{*}{$\begin{array}{c}\text { Measurement } \\
\text { Intervals }\end{array}$} & \multicolumn{9}{|c|}{ Bacterial Concrete } \\
\cline { 2 - 8 } $\mathrm{t}_{\mathrm{i}}(\mathrm{min})$ & \multicolumn{2}{|c|}{$\mathrm{M} 20$} & \multicolumn{2}{c|}{$\mathrm{M} 40$} & \multicolumn{2}{c|}{$\mathrm{M} 60$} & \multicolumn{2}{c|}{$\mathrm{M} 80$} \\
\cline { 2 - 8 } & $\mathrm{m}_{\mathrm{o}}=2.51 \mathrm{~kg}$ & $\mathrm{~m}_{\mathrm{o}}=2.53 \mathrm{~kg}$ & $\mathrm{~m}_{\mathrm{o}}=2.60 \mathrm{~kg}$ & \multicolumn{2}{c|}{$\mathrm{m}_{\mathrm{o}}=2.64 \mathrm{~kg}$} \\
\cline { 2 - 8 } & $\mathrm{m}_{\mathrm{i}}(\mathrm{kg})$ & $\mathrm{M}_{\mathrm{i}}(\%)$ & $\mathrm{m}_{\mathrm{i}}(\mathrm{kg})$ & $\mathrm{M}_{\mathrm{i}}(\%)$ & $\mathrm{m}_{\mathrm{i}}(\mathrm{kg})$ & $\mathrm{M}_{\mathrm{i}}(\%)$ & $\mathrm{m}_{\mathrm{i}}(\mathrm{kg})$ & $\mathrm{M}_{\mathrm{i}}(\%)$ \\
\hline 0 & 2.51 & 0.00 & 2.53 & 0.00 & 2.60 & 0.00 & 2.64 & 0.00 \\
\hline 15 & 2.52 & 0.40 & 2.54 & 0.40 & 2.61 & 0.38 & 2.65 & 0.38 \\
\hline 30 & 2.54 & 1.20 & 2.55 & 0.79 & 2.62 & 0.77 & 2.65 & 0.38 \\
\hline 60 & 2.56 & 1.99 & 2.55 & 0.79 & 2.62 & 0.77 & 2.65 & 0.38 \\
\hline 90 & 2.58 & 2.79 & 2.56 & 1.19 & 2.62 & 0.77 & 2.65 & 0.38 \\
\hline 180 & 2.58 & 2.79 & 2.56 & 1.19 & 2.62 & 0.77 & 2.65 & 0.38 \\
\hline 480 & 2.58 & 2.79 & 2.56 & 1.19 & 2.62 & 0.77 & 2.65 & 0.38 \\
\hline 1440 & 2.58 & 2.79 & 2.56 & 1.19 & 2.62 & 0.77 & 2.65 & 0.38 \\
\hline 2880 & 2.58 & 2.79 & 2.56 & 1.19 & 2.62 & 0.77 & 2.65 & 0.38 \\
\hline
\end{tabular}




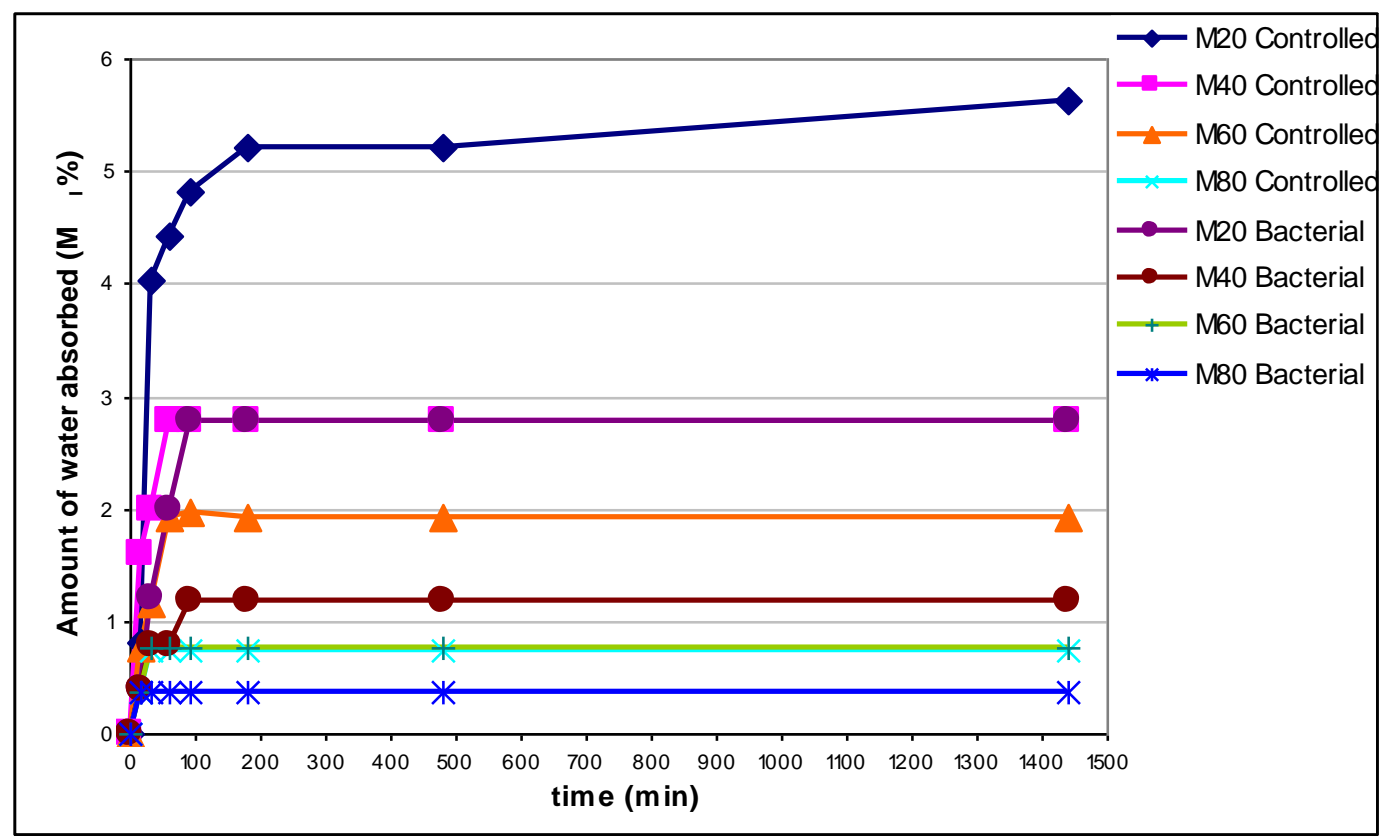

Fig 2: Plot showing amount of water absorption with time for different grades of controlled and bacterial specimens

Table 3: Water Absorption Capacity (WAC), Volume of Permeable Voids and Apparent porosity of controlled and bacterial concrete specimens for different grades

\begin{tabular}{|c|c|c|c|c|c|c|c|c|}
\hline & \multicolumn{3}{|c|}{ Controlled Concrete } & \multicolumn{5}{c|}{ Bacterial Concrete } \\
\cline { 2 - 9 } & M20 & M40 & M60 & M80 & M20 & M40 & M60 & M80 \\
\hline $\mathrm{m}_{\max }(\mathrm{kg})$ & 2.63 & 2.58 & 2.64 & 2.67 & 2.58 & 2.56 & 2.62 & 2.65 \\
\hline $\mathrm{m}_{\mathrm{d}}(\mathrm{kg})$ & 2.49 & 2.51 & 2.59 & 2.63 & 2.51 & 2.53 & 2.60 & 2.64 \\
\hline $\mathrm{m}_{\mathrm{s}}(\mathrm{kg})$ & 1.49 & 1.45 & 1.50 & 1.51 & 1.46 & 1.46 & 1.50 & 1.51 \\
\hline Water Absorption Capacity (WAC) $(\%)$ & 5.6 & 2.8 & 1.9 & 0.8 & 2.8 & 1.2 & 0.8 & 0.4 \\
\hline VPV & 14 & 7 & 5 & 4 & 7 & 3 & 2 & 1 \\
\hline Apparent porosity (\%) & 11.4 & 5.5 & 3.8 & 1.4 & 5.7 & 2.1 & 1.1 & 0.5 \\
\hline
\end{tabular}

Table 4: Durability Classification as per ASTM C642

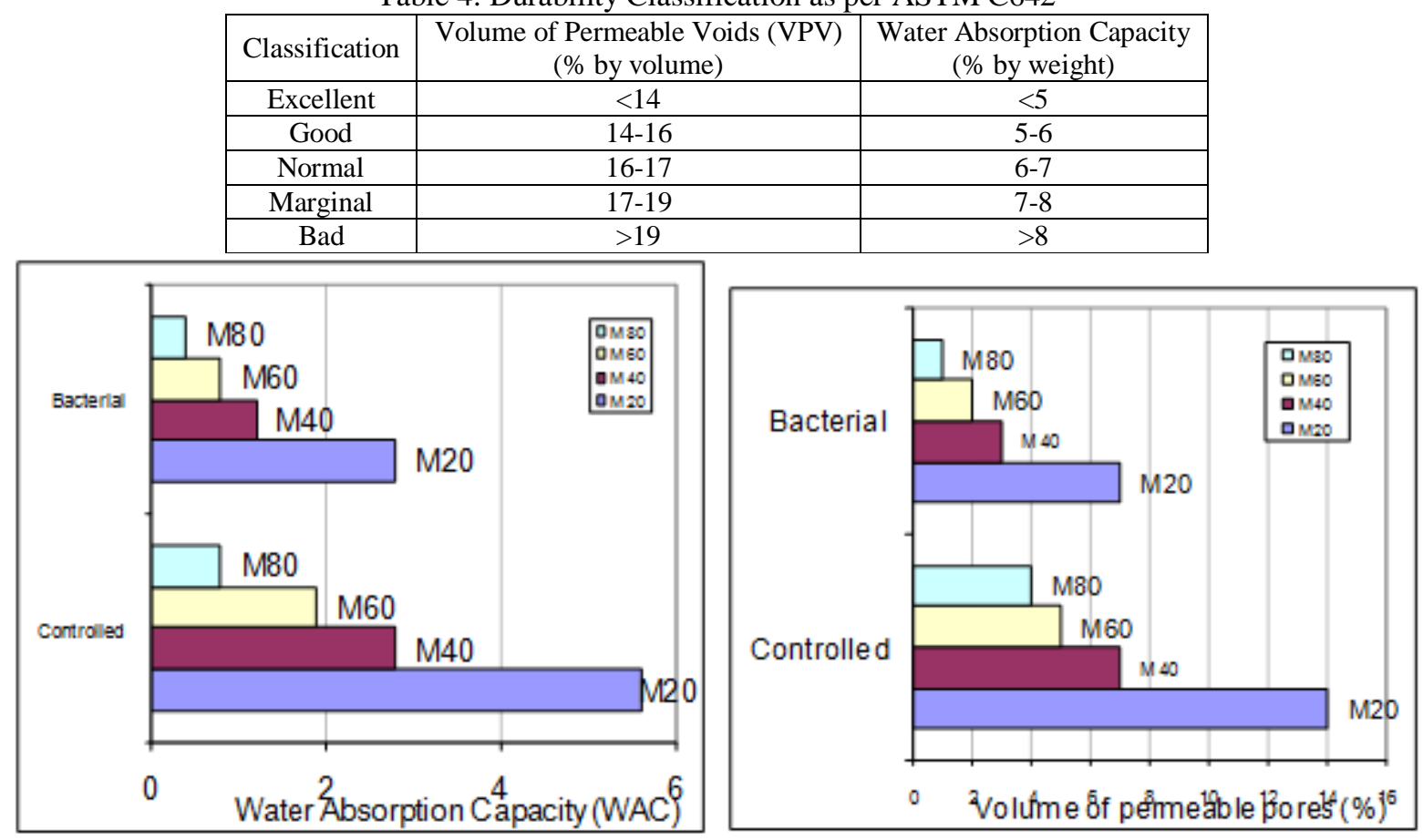

Fig 3: Water absorption Capacity and volume of permeable pore space of controlled and bacterial concrete 
Table 5: The gain in mass per unit area over the density of water 'I' (m) at regular intervals of time ' $t$ ' (min)

\begin{tabular}{|c|c|c|c|c|c|c|c|}
\hline \multicolumn{7}{|c|}{ Controlled Concrete } \\
\hline \multicolumn{2}{|c|}{ M20 } & \multicolumn{2}{c|}{ M40 } & \multicolumn{2}{c|}{ M60 } & \multicolumn{2}{c|}{ M80 } \\
\hline $\begin{array}{c}\text { I x 10- } \\
3(\mathrm{~m})\end{array}$ & $\mathrm{t}(\mathrm{min})$ & $\begin{array}{c}\text { I x 10- } \\
3 \\
(\mathrm{~m})\end{array}$ & $\mathrm{t}(\mathrm{min})$ & $\begin{array}{c}\text { I x 10 } \\
3 \\
(\mathrm{~m})\end{array}$ & $\mathrm{t}(\mathrm{min})$ & $\begin{array}{c}\mathrm{I} \times 10^{-} \\
(\mathrm{m})\end{array}$ & $\mathrm{t}(\mathrm{min})$ \\
\hline 0 & 0 & 0 & 0 & 0 & 0 & 0 & 0 \\
\hline 0.0005 & 15 & 0.0004 & 15 & 0.0003 & 15 & 0.0002 & 15 \\
\hline 0.0007 & 30 & 0.0005 & 30 & 0.0004 & 30 & 0.0003 & 30 \\
\hline 0.001 & 60 & 0.0007 & 60 & 0.0005 & 60 & 0.0004 & 60 \\
\hline 0.0014 & 120 & 0.001 & 120 & 0.0008 & 120 & 0.0006 & 120 \\
\hline 0.0019 & 240 & 0.0014 & 240 & 0.0011 & 240 & 0.0009 & 240 \\
\hline 0.0024 & 360 & 0.0017 & 360 & 0.0013 & 360 & 0.001 & 360 \\
\hline 0.0047 & 1440 & 0.0035 & 1440 & 0.0027 & 1440 & 0.0021 & 1440 \\
\hline 0.0067 & 2880 & 0.0049 & 2880 & 0.0038 & 2880 & 0.003 & 2880 \\
\hline 0.0082 & 4320 & 0.006 & 4320 & 0.00437 & 4320 & 0.0036 & 4320 \\
\hline
\end{tabular}

\begin{tabular}{|c|c|c|c|c|c|c|c|}
\hline \multicolumn{7}{|c|}{ Bacterial Concrete } \\
\hline \multicolumn{2}{|c|}{ M20 M40 } & \multicolumn{2}{c|}{ M60 } & \multicolumn{2}{c|}{ M80 } \\
\hline $\mathrm{I} \times 10^{-3}(\mathrm{~m})$ & $\mathrm{t}(\mathrm{min})$ & $\mathrm{I} \times 10^{-3}(\mathrm{~m})$ & $\mathrm{t}(\mathrm{min})$ & $\mathrm{I} \times 10^{-3}(\mathrm{~m})$ & $\mathrm{t}(\mathrm{min})$ & $\mathrm{I} \times 10^{-3}(\mathrm{~m})$ & $\mathrm{t}(\mathrm{min})$ \\
\hline 0 & 0 & 0 & 0 & 0 & 0 & 0 & 0 \\
\hline 0.00045 & 15 & 0.0003 & 15 & 0.0002 & 15 & 0.0002 & 15 \\
\hline 0.00055 & 30 & 0.0004 & 30 & 0.0003 & 30 & 0.0003 & 30 \\
\hline 0.00075 & 60 & 0.0005 & 60 & 0.0005 & 60 & 0.0004 & 60 \\
\hline 0.001 & 120 & 0.0008 & 120 & 0.0007 & 120 & 0.0006 & 120 \\
\hline 0.00145 & 240 & 0.0011 & 240 & 0.001 & 240 & 0.0008 & 240 \\
\hline 0.00175 & 360 & 0.0013 & 360 & 0.0012 & 360 & 0.001 & 360 \\
\hline 0.00355 & 1440 & 0.0027 & 1440 & 0.0024 & 1440 & 0.0019 & 1440 \\
\hline 0.00495 & 2880 & 0.0038 & 2880 & 0.0033 & 2880 & 0.0027 & 2880 \\
\hline 0.00635 & 4320 & 0.0047 & 4320 & 0.0041 & 4320 & 0.0034 & 4320 \\
\hline
\end{tabular}

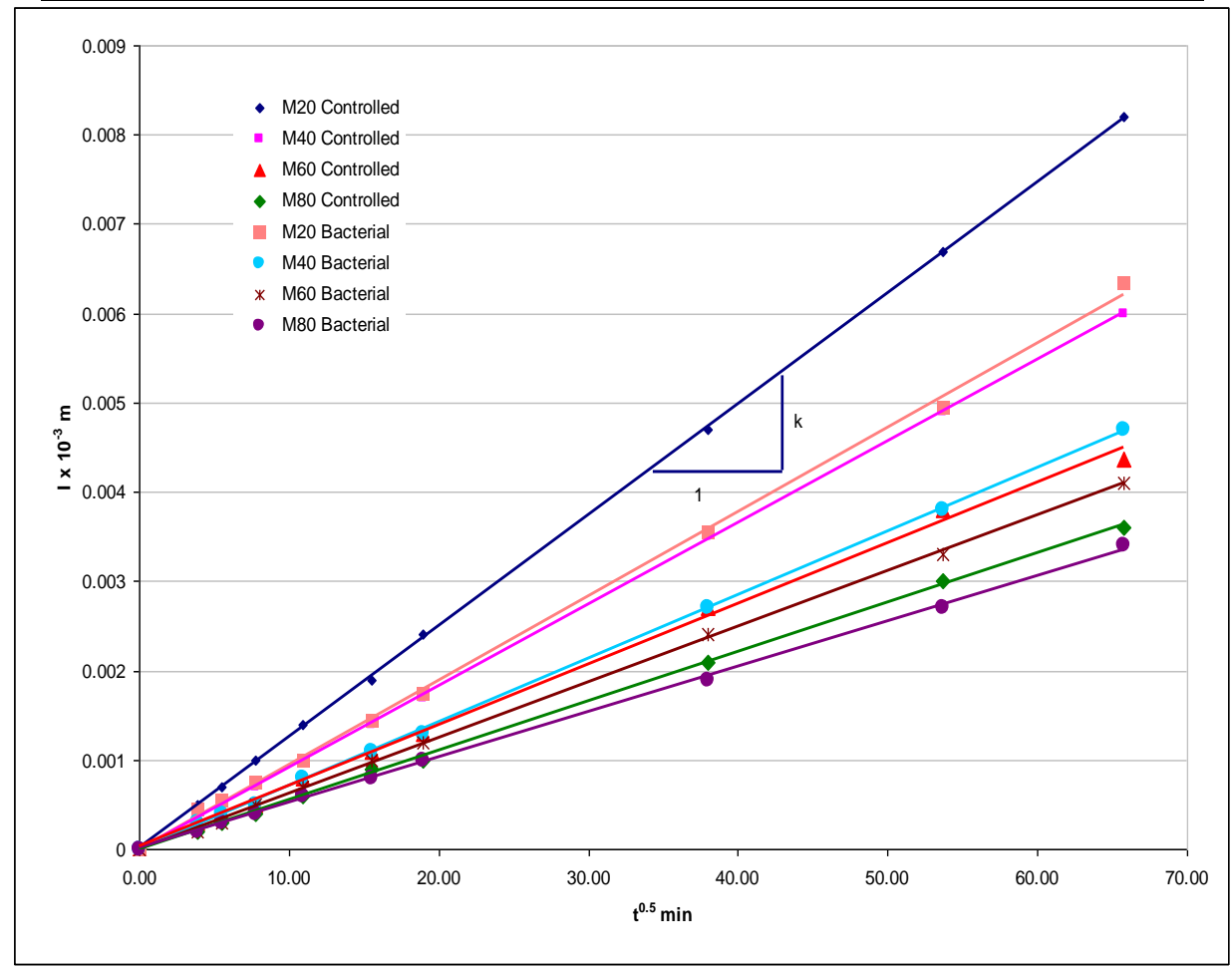

Fig 4: Plot between I- $\sqrt{t}$ to calculate sorptivity coefficient $(\mathrm{k})$ 
Table 6: Sorptivity Coefficients of controlled and bacterial concrete specimens of different grades

\begin{tabular}{|c|c|c|}
\hline \multirow{4}{*}{ Controlled Concrete } & Grade of the Concrete & $\begin{array}{c}\text { Sorptivity Coefficient }(\mathrm{k}) \times 10^{-3} \\
\mathrm{~m} / \mathrm{min}^{0.5}\end{array}$ \\
\cline { 2 - 3 } & M20 & 0.124 \\
\cline { 2 - 3 } & M40 & 0.092 \\
\cline { 2 - 3 } & M60 & 0.07 \\
\hline \multirow{3}{*}{ Bacterial Concrete } & M80 & 0.055 \\
\cline { 2 - 3 } & M20 & 0.091 \\
\cline { 2 - 3 } & M40 & 0.071 \\
\cline { 2 - 3 } & M60 & 0.062 \\
\hline
\end{tabular}

Table 7: Porosity of Concrete $(\eta)$ in $\%$ of various grades at different ages

\begin{tabular}{|c|c|c|c|c|}
\hline \multirow{4}{*}{$\begin{array}{c}\text { Grade of } \\
\text { Concrete }\end{array}$} & \multicolumn{3}{|c|}{ Porosity of Concrete $(\eta)(\%)$} \\
\cline { 2 - 5 } Controlled & M20 & 28 days & 60 days & 90 days \\
\cline { 2 - 5 } Concrete & M40 & 3.65 & 3.44 & 3.41 \\
\cline { 2 - 5 } & M60 & 3.22 & 3.03 & 2.97 \\
\cline { 2 - 5 } & M80 & 2.35 & 2.11 & 1.96 \\
\hline \multirow{3}{*}{$\begin{array}{c}\text { Bacterial } \\
\text { Concrete }\end{array}$} & M20 & 2.22 & 1.98 & 1.72 \\
\cline { 2 - 5 } & M40 & 1.09 & 0.91 & 0.95 \\
\cline { 2 - 5 } & M60 & 1.02 & 0.93 & 0.88 \\
\cline { 2 - 5 } & M80 & 0.87 & 0.82 & 0.77 \\
\hline
\end{tabular}

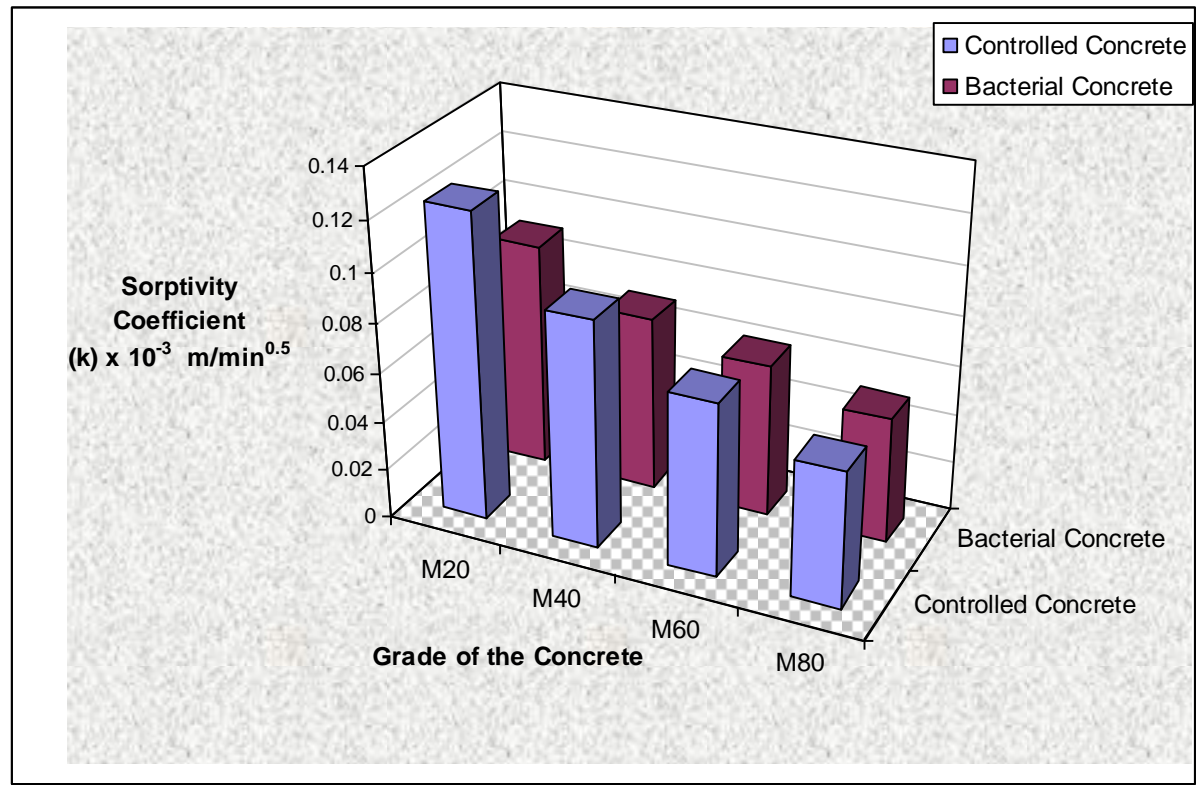

Fig 5: Variation of sorptivity of controlled and bacterial specimens for different grades 


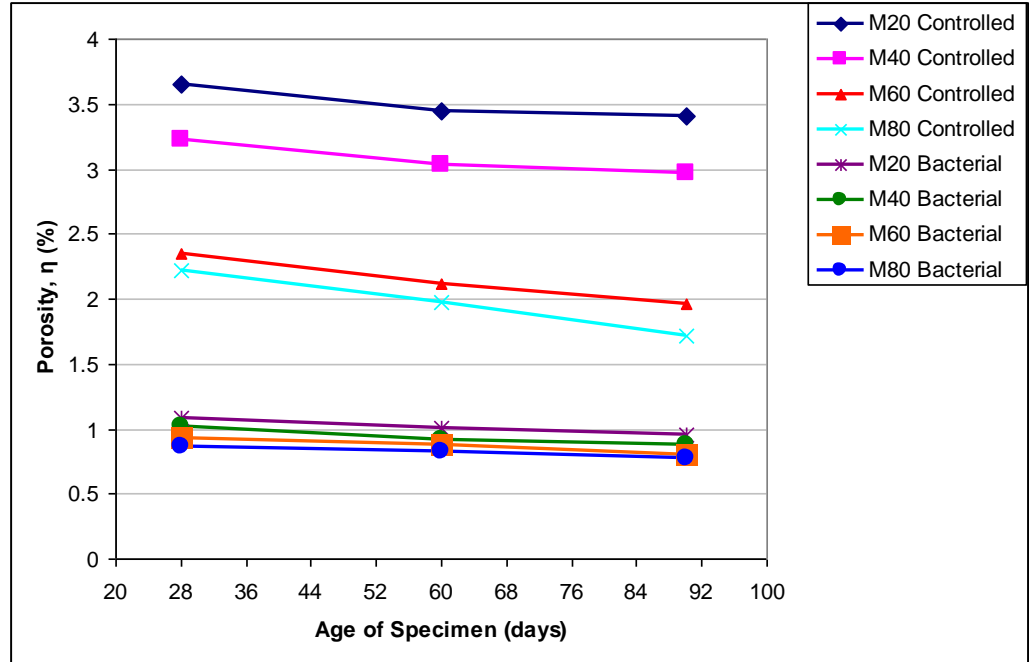

Fig 6: Variation of porosity with age for different grades of controlled and bacterial specimens

\section{Discussions}

Table 1 presents the elemental composition of bacterial concrete which has predominantly high calcium oxide content indicating the presence of calcium precipitation. Fig 1 shows amount of water absorption with time for different grades of controlled and bacterial specimens. Table 3 shows the Water Absorption Capacity (WAC), Volume of Permeable Voids and Apparent porosity for different grades of controlled and bacterial concrete specimens. Fig 2 shows the Water absorption Capacity and volume of permeable pore space in controlled and bacterial concrete for different grades.

Water Absorption Capacity (WAC), volume of permeable pores (VPV) and apparent porosity of bacterial concrete specimens are reduced by nearly $50 \%$. Porosity of concrete specimens are reduced by nearly $70 \%$ with induction of bacteria into concrete.

Table 5 shows plot between the gain in mass per unit area over the density of water (I) and the square root of the elapsed time $(\sqrt{ } \mathrm{t})$. The slope of the line of best fit of these points is reported as the sorptivity coefficient (k). From Table 6 it is apparent that sorptivity decreases systematically for bacteria treated concrete specimens for all grades.

The sorptivity coefficients of bacterial concrete specimens are low for all grades when compared with corresponding grades of controlled concrete specimens because the pores in the bulk paste or in the interfaces between aggregate and cement paste is filled by the mineral precipitation hence, the capillary pores are reduced. The high sorptivity values are obtained for controlled concrete than bacterial concrete.

\section{Conclusion}

Based on limited experimental investigation concerning the water absorption and sorptivity of concrete, the following observations are:

1. It was observed that the water absorption characteristics of the concrete specimens decreased with induction of bacteria in concrete. As can be expected, the water absorption of both the controlled and bacterial concretes has a decreasing tendency with the increase in the curing period. The differences in the water absorption characteristics of the different grades of controlled and bacteria treated concrete specimens became more significant and were remarkably lower for bacteria treated specimens. It is well known that to some extent the pozzolanic reactions contribute to the refinement of the binder capillary porosity, with its direct consequences on the improvement of the durability characteristics of the concrete as observed in M60 and M80 grades but in the present case bacteria produced minerals plug the pores of the concrete modifying the pore structure of the cement-sand matrix.

2. In the literatures, it has been shown that the porosity is not only the parameter influencing the strength of concrete, but many other factors such as pore size distribution, micro-cracks, interface, and so on are also important factors that determine mechanical properties of concrete.

3. Bacteria treated concrete samples gave the lower sorptivity and porosity values compared to control concrete. This means that the time taken for the water to rise by capillary action in bacterial concrete are longer and thus proved that these concrete are less porous compared to the control concrete. The possible reason for this is calcite mineral precipitation in the pores due to microbial activities of B. subtilus, reduced the average pore radius of concrete by blocking the large voids (pore discontinuity) in the hydrated cement 
paste and finer particles of Silicafume fitting in between cement particles also plays a role in high strength grade bacterial concretes.

\section{References}

[1]. Meng, B., "Characterization of pore structure for the interpretation of moisture transport", in THIEL, M.J. [ED.], Conservation of stone and other materials. Proceedings of the International RILEM/UNESCO Congress, Paris, 29 June-1 July 1993. London, E \& F.N. SPON, 1993, pp. 155-162.

[2]. Claisse, P. A. (1997). "Absorption and Sorptivity of Cover Concrete." Journal of Materials in Civil Engineering, 9(3), 105-110.

[3]. Khan, M.I., 2003, "Permeation of High Performance Concrete" Journal of Materials in Civil Engineering, ASCE, Vol. 15, pp. 84-92.

[4]. Sabir, B. B.; Wild, S. and O'Farrel M. "A water sorptivity test for mortar and concrete". Materials and Structures, Vol 31, No 213, 1998, p. 568-574.

[5]. ASTM C642 (1993) Standard Test Method for Specific Gravity, Absorption, and voids in Hardened concrete. American Standard of testing Materials, 1982, pp.395-97

[6]. Day RL, Marsh BK (1988) Measurement of porosity in blended cement pastes. Cement and Concrete Research 18:63-73

[7]. German Standard DIN 52 617:1987 (1987). Determination of the water absorption coefficient of construction material.

[8]. Mccarter, W. J., "Influence of surface finish on sorptivity on concrete", Journal of Materials in Civil Engineering, Vol. 5, No 1, pp. 130-136, 1993.

[9]. Claisse, p. A., elsayad, h. I. And shabaan, i. G., "Absorption and sorptivity of cover concrete", Journal of Materials in Civil Engineering, pp. 105-110, 1997.

[10]. Parrott, 1.j., "Variations of water absorption rate and porosity with depth from an exposed concrete surface: Effects of exposure conditions and cement type", Cement and Concrete Research, Vol. 22, pp. 1077-1088, 1992. 